\title{
砂山形成過程におけるゆらぎのダイナミクス
}

\section{Dynamics of Fluctuation in Formation Process of a Sandpile}

\section{1. 研究の背景と目的}

砂山のダイナミクスについてさまざまな実験が行わ れており，砂山上のなだれの規模の分布なども実験室 において測定されている。砂山の数理モデルとしては Bak らの Sandpile Model において伯抄のサイズ分布 のパワースペクトルがベキ的になることが知られてお り，SOCのモデルとしても注日を集めた。

本論文ではなだれを含む砂山形成過程のダイナミク スに着目し，形成過程の特徽を表す量として頂点位置 の変動に焦点を絞り, 離散要素法を用いて砂山形成過 程のゆらぎを調べるために頂点の時系列のパワースペ クトルを測定した。

\section{2. 主な研究成果}

砂山の上空から 1 粒子ごと時間間隔 Tで供給し続け ることによって形成過程を実現した。頂点位置の時系 列のパワースペクトル $\mathrm{S}$ (f) はベキ的になり, ベキの 指数 $\alpha$ は Tに依存する。Tが小さいときには，粒子の 供給量が多いために砂山表面は流動状態を維持する。 このとき $\mathrm{S}(\mathrm{f}) \sim 1 / \mathrm{f}$ となり, 時系列は特徴的時間を 持たない。逆にTがなだれの継続時間より大きいと き，間欠的に発生するなだれを除いて砂山表面は長時 間固体的状態をたもち， $\alpha$ はTが大きくなるにつれて - 2 に近づく傾向がみられた。Tがこれらの中間の領 域ではTが変化しても $\alpha$ は近似的に一定值をとるとい う現象が現れた。

占部干由 (Chiyori Urabe)

京都大学基礎物理学研究所

（作606-8502 京都市左京区北白川追分町）TEL 075-753-7055

Yukawa Institute for Theoretical Physics, Kyoto University (Oiwake-cho Kitashirakawa Sakyou-ku. Kyoto 606-8502. Japan)

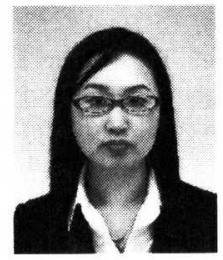

<著者紹介>

1998年奈良女子大学理学部卒、2006年 3 月京 都大学 人間・環境学博士。同年 4 月より京 都大学基碛物理学研究所非常勤講師 専門: 非平衡統計力学
Tが小さいときにはなだれによる頂点の移動が支配 的となるため，なだれと頂点移動の関係から S (f) が $1 / \mathrm{f}$ 的になる原因を調查した。2 次元・ 3 次元の砂山 でなだれの向きの時間変化を粒子の運動エネルギーや 運動量を用いてそ机ぞれ測定した。シミュレーション の結果からなだれの方向は時間的に変化し，なだれの 方向と頂点位置の間に相関があり，そ扎らのパワース ペクトルはベキ的であり，長い時間スケールでは同じ 指数を示すことがわかった。

2 次元の砂山の場合には，なだれの方向は右左の 2 值で表される。2 值化された時系列については巾関数 で表される待ち時間分布之時系列のパワースペクトル の関係が解析的に求められており, 本研究においても 近似的に同様の関係が確認された。

\section{3. 今後の展開}

取り扱う系が大きくなるほどなだれで流される粒子 数は多くなり，その方向の時間的変化は防災上重要な 問題となる。今後, 待ち時間分布が巾的になる原因を シミュレーションと理論の両面から究明したい。

最後に本研究の遂行にあたり, 京都大学の冨田博之 先生と早川尚男先生に常に的確なご教示をいただけた ことに心より感謝申し上げます。京都大学吉田南構内 非平衡物理グループの皆様には惜しみないご協力をい ただけたことを感謝いたします。

\section{文献リスト}

1) 占部下由：“砂山形成過程における頂点移動のダイナミク ス”, 複雑流体の構造形成と崩壊の数理 (Mathematical Aspects of Pattern Formation in Complex Fluids) RIMS 研究集会報告集, 数理解析研究所講究録, 1413, 7074 (2005)

2 ) Urabe, C.: "Dynamics of Fluctuation of the Top Location of a Sandpile", Journal of the Physical Society of Japan, 74, 2475-2479 (2005)

3 ) 占部千由：“砂山形成過程における頂点移動のダイナミク ス II ", 複雑流体の数理とその応用 (Mathematical Aspects of Complex Fluids and Their Applications) RIMS 研究集会報告集, 数理解析研究所講究録, 1472, 7180 (2006)

(学位取得は 2006 年 3 月, 京都大学) 